\title{
Semiotiese ontleding van Daniël 2
}

\author{
Marius Nel \\ Noordwes-Universiteit (Potchefstroom-kampus)
}

\begin{abstract}
A Semiotic analysis of Daniel 2

In an accompanying article the method of semiotics is described and applied in relation to Daniel 1. In this article Daniel 2 is semiotically analysed. The narrative uses ring composition to emphasize that God is able to reveal secrets. Daniel 2 is characterized by more qualifications than functions, attributable to the length of the narrative but also to the long description of the dream and its interpretation. Transformations can be found in the conversation between the king and his wise men, the law of the king, the conversation between Daniel and Arioch, the prayer of the four Jews, the revelation of the dream to them, their song of praise, and Daniel's conversation with the king. The dreams' transformation lies in God's destroying and absorption of the previous kingdoms. The plot lies in the engagement between the king and his wise men, and in the dream and its interpretation. As is the case in Daniel 1, the author emphasized the sovereignty of God and the responsibility of believers as main values.
\end{abstract}

\section{INLEIDING}

In meegaande artikel ${ }^{1}$ is die metodiek van semiotiek geskets, voor dit van toepassing gemaak is op Daniël 1. In hierdie artikel word daarop voortgebou wanneer Daniël 2 semioties ontleed word.

\section{SEMIOTIESE ONTLEDING}

Die doel van struktuur-analise is om te verstaan hoe literatuur aanmekaar gesit is (Watson 1984:39). Die veronderstelling is dat daar vaste wette is wat bepaal hoe literatuur werk (Levi-Strauss 1963:224; Culley 1992:10). Soos meeste sprekers nie eksplisiete kennis van die reëls het wat die gebruik van taal beheers nie, kies meeste skrywers nie doelbewus om die wette te volg wat literatuur bepaal nie. Tog volg literatuur sekere konvensies wat veroorsaak dat dit iets beteken (Milne 1988:61). Dit beteken dat die betekenis van 'n teks binne die diep strukture van die teks gevind word, eerder as in die intensies van die skrywer of persepsies van die lesers (De Saussure 1959:65-

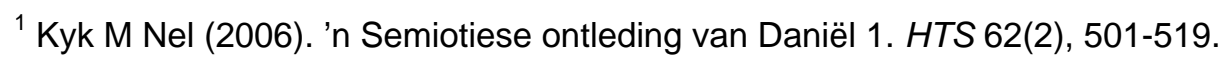




\section{Semiotiese ontleding van Daniël 2}

70). Die navorser probeer om die werk op 'n manier te verstaan wat die skrywer self nie doelbewus beplan het nie. Die navorser doen dit deur die teks se kommunikatiewe strategie te ondersoek (Patte \& Patte 1978:11).

\section{$2.1 \quad$ Verdeling in leeseenhede}

Die vertelling in Daniël 2 is in die vorm van 'n dialoog. Die merkers in die teks dui dit duidelik aan. Die feit dat die vertelling in dialoogvorm is, beklemtoon dat die gedeelte geïnterpreteer moet word volgens die reëls wat vir dialoë of gesprekke geld (Calloud 1976:72). Gesprekke wat in die Bybel opgeteken is, is uiteraard gerekonstrueer (Polzin 1974:187). Die Bybelse weergawe is nie 'n woord-vir-woord weergawe van wat in werklikheid gesê is in gevalle waar die skrywer 'n historiese rekonstruksie gee nie. Die skrywer gee die gesprek weer om sy doel te dien: om nodige agtergrondgegewens te verskaf of die intrige te akkomodeer (Calloud 1976:19). Die Daniëlboek is nie 'n historiese weergawe nie.

\subsection{Temas}

Die temas van die perikoopeenhede is soos volg:

- die koning droom, en roep die wyses en vra raad - vv 1-3

- die wyses vra dat die koning die droom vertel - v 4

- die koning vra dat hulle die droom ook moet vertel - vv 5-7

- die wyses vra vir 'n tweede keer dat die droom vertel word - v 7

- die koning dring aan dat die wyses die droom ook moet openbaar - vv 8-9

- die wyses erken dat hulle nie die droom kan openbaar of die uitleg gee nie - vv 10-11

- die koning beveel dat alle wyses gedood word - vv 12-13

- Daniël vra hoekom die wyses doodgemaak moet word - v 14-15

- Daniël vra uitstel, en versoek sy vriende om saam met hom te bid - v 16

- Daniël ontvang die uitleg, en prys God - vv 17-23

- Daniël vra Arjok om hom na die koning te neem - v 24

- Arjok stel die koning in kennis dat hy iemand het wat die droom kan uitlê - v 25

- die koning vra Daniël of hy die droom kan uitlê - v 26

- Daniël erken: niemand kan die droom uitlê nie, maar God kan - vv 2728

- Daniël vertel die inhoud van die droom- vv 29-36

- Daniël verklaar die droom - vv 37-45 
- die koning vereer Daniël en erken dat Daniël se God die grootste is vv 46-47

- die koning vereer Daniël, sowel as sy drie vriende - vv 48-49.

Perikoopeenheid 1 bevat die tema van die vertelling: die koning het gedroom. Dit dien as opskrif vir die verhaal. Die koning was ontsteld oor sy droom. 'n Ingewikkelde ringskomposisie omvat die gesprek tussen die koning en die wyses. Dit kan soos volg geskematiseer word:

$\begin{array}{ll}\text { koning: } & \text { wat beteken die droom? } \\ \text { wyse manne: } & \text { vertel ons die droom } \\ \text { koning: } & \text { gee die droom en sy uitleg, of julle is dood } \\ \text { wyse manne: } & \text { vertel ons die droom } \\ \text { koning: } & \begin{array}{l}\text { vertel die droom sodat ek weet of julle die } \\ \text { uitleg kan gee! }\end{array} \\ \text { wyse manne: } & \text { niemand kan nie! } \\ \text { koning: } & \text { dan is julle dood! }\end{array}$

Dat die koning vier spreekbeurte kry teenoor die wyses se drie, gee iets van sy mag en die gewig van sy woorde weer - die feit dat hy roep en die wyses moet kom, vra en die wyses moet antwoord. Die eerste en laaste woord behoort aan hom. Hy proklameer die begin en die einde van die wyses van Babel.

Die volgende reeks perikoopeenhede bevat Daniël se reaksie op die proklamasie, wat direk op hom betrekking het. Die eerste twee perikoopeenhede verwys na sy navraag daaroor, en sy versoek. Die volgende twee perikoopeenhede vertel hoe Daniël sy vriende byeen roep, hulle saam bid en hy die droom en sy interpretasie kry. Die volgende drie perikoopeenhede het te doen met die transaksies wat aangegaan word sodat Daniël uiteindelik voor die koning staan. Die laaste twee bevat dan die oorwig (pro rata) van die woorde: Daniël vertel wat die droom behels en wat die uitleg is (17 en 18).

Die derde reeks perikoopeenhede handel oor die verering van Daniël, sy God en sy vriende (Van Wyk 1983:183-185). Skematies kan die struktuur so voorgestel word:

\begin{tabular}{|lll|}
\hline 19 & A1 & $\begin{array}{l}\text { die koning vereer Daniël } \\
\text { B1 die koning erken dat Daniël } \\
\text { se God die grootste is } \\
\text { die koning vereer Daniël }\end{array}$ \\
21 & A2 & $\begin{array}{l}\text { B2 die koning vereer Daniël se } \\
\text { drie vriende }\end{array}$ \\
\hline
\end{tabular}




\section{Semiotiese ontleding van Daniël 2}

In die hart van die vertelling kom perikoopeenhede 11 en 12 voor (in terme van perikoopeenhede is dit getallegewyse opvallend ook in die middel). Dit verwys na die gebede van Daniël en sy vriende wat tot die openbaring van die droom lei. Dit word voorafgegaan deur die sketsing van die probleem - die wyses kan nie die droom uitlê nie, en die gevolg daarvan - die koning proklameer dat alle wyses doodgemaak word (Hartman \& DiLella 1978:139). Perikoopeenhede 11 en 12 vorm die hoogtepunt van die ontsluiting, wat voortgesit word in die res van die vertelling. Dit het die opvallende gevolg dat die spanningsvlak baie gou ontlaai word kort nadat dit geformuleer is. Die rede hiervoor is duidelik: die skrywer probeer nie 'n verhaal saamstel wat verwys na die ontplooiing van 'n krisis en die oplossing daarvan nie. Hy plaas alle klem op God wat die openbaarder van geheime is. Dit beteken dat 'n kwart van alle leeseenhede God en sy mag as tema het, en dat meer as dertig persent van die ontknoping daaraan gewy word. God se mag oor die geheime van die toekoms vorm die fokuspunt van die vertelling. Joubert (1979:36) teken die basiese patroon van die vertelling soos volg:

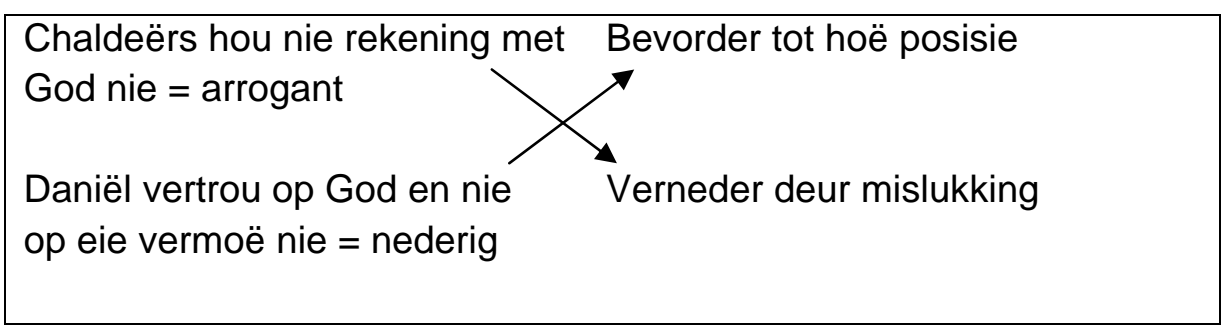

Die skrywer wy die grootste deel van die loflied (vv 20-23) aan die beskrywing van God se mag. Aan die einde noem die skrywer weer hoekom Daniël die loflied sing (v 23). Sommige eksegete meen dat die loflied 'n byvoeging tot die vertelling is, en dieselfde rol vervul as die lofliedere wat in die apokriewe (deutero-kanonieke) literatuur van die derde hoofstuk voorkom. Ek stem nie saam nie. Die struktuur van die vertelling dui aan dat die skrywer die loflied gebruik om die doel met sy vertelling te beklemtoon, naamlik om God se mag om geheime te openbaar, te beklemtoon.

Die droom en uitleg deur Daniël vertoon ook 'n besondere struktuur wat op herhaling dui. As die droom en uitleg in terme van die elemente van die beeld gesien word, lyk dit so: 


\begin{tabular}{|c|c|c|c|}
\hline $\begin{array}{l}\text { v } 31 \\
\text { v } 32 \\
\text { v } 33 \\
\text { v } 34 \\
\text { v } 35\end{array}$ & $\begin{array}{l}\text { BEELD } \\
\text { hoof } \\
\text { bors } \\
\text { maag en heupe } \\
\text { bene } \\
\text { voete } \\
\text { steen } \\
\text { steen word berg }\end{array}$ & $\begin{array}{l}\text { v } 36 \\
\text { v } 37-38 \\
\text { vv } 39 \\
\text { vv } 40 \\
\text { vv 44-45 }\end{array}$ & $\begin{array}{l}\text { UITLEG } \\
\text { eerste ryk } \\
\text { tweede ryk } \\
\text { derde ryk } \\
\text { vierde ryk } \\
\text { vv } 41-43 \text { vyfde ryk } \\
\text { goddelike ryk }\end{array}$ \\
\hline & & & \\
\hline
\end{tabular}

\subsection{Pertinente transformasies}

Wat opval as die verhaal aan die hand van pertinente transformasies gelees word, is dat daar baie meer kwalifikasies as in Daniël 1 is. Met kwalifikasie word bedoel "om te wees" of "om te hê", teenoor funksie, "om te doen" (Calloud 1976:18; 1992:131). Dié prosesse word as kwalifikasies of funksies beskryf. Dit het nie net met die lengte van die verhaal te doen nie, maar ook met die aard. Die beskrywing van die beeld word in terme van kwalifikasies gedoen (vv 31b-42a). Die ryke word opeenvolgend beskryf, in terme van unieke eienskappe. Die koning se gemoedstoestand word ook as kwalifikasies beskryf: hy is bekommerd oor sy droom ( $v 1 b)$ en hy is slapeloos ( $v 1 c$ ). Hy vertel aan die wyse manne dat hy ontsteld is (v 3c). Wanneer die wyses nie sy droom kan bekend maak en die uitleg daarvan gee nie, is hy woedend (v 12a).

Dat kwalifikasies baie aandag kry, beteken nie dat daar nie volop aandag aan transformasies gegee word nie. Die transformasies lê op verskeie vlakke. Die koning roep die wyse manne en vra hulle uit oor sy droom. Hieruit vloei 'n gesprek. Die gevolg daarvan is die dekreet van die koning. Daniël doen navraag by Arjok hoekom die koning se proklamasie so genadeloos is. Hy en sy vriende bid, en God gee die uitleg. Daniël prys God deur te vertel waartoe Hy alles in staat is. Hierna vertel Daniël vir die koning wat die droom en uitleg is (Fewell 1991:29).

In die droom gebeur daar ook iets: God se koninkryk oorweldig die oorheersende wêreldryke. Wanneer Daniël sy uitleg van die droom voltooi het, reageer die koning deur hulde aan hom te bring. Ter afsluiting vra Daniël dat sy vriende ook voordeel mag trek, en hulle word in belangrike posisies onder hom aangestel. 


\subsection{Verskillende narratiewe binne die vertelling}

Die verhaal kan op grond van die pertinente transformasies soos volg opgesom word:

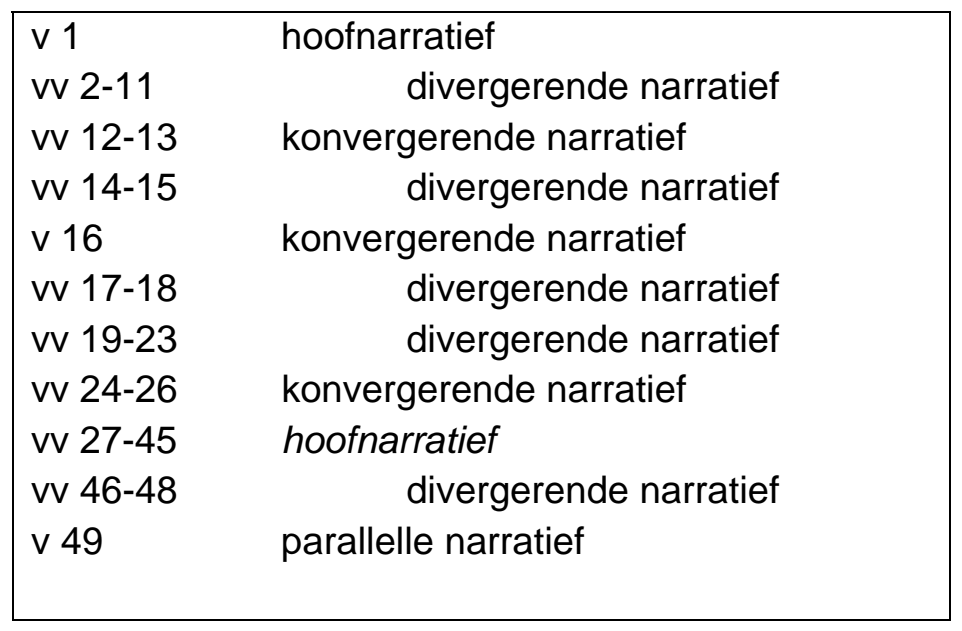

Die doel met die identifisering van die elementêre narratief deur 'n onderskeid te tref tussen die verskillende elemente daarvan, is om onderbrekings in die formele hiërargiese patroon aan te dui, asook die breuke in die logiese narratiewe ontwikkeling. Die primêre narratief bestaan uit die slagaar van die verhaal, naamlik die vertelling van die droom en die betekenis daarvan. Die verhaal bevat ook verskeie divergerende narratiewe (vyf in totaal), wat die formele patroon onderbreek, maar sonder om die logiese narratiewe ontwikkeling te onderbreek. Die waarde van die divergerende narratiewe is dat dit 'n nuwe narratiewe ontwikkeling is wat gebaseer is op ' $n$ interpretasie van die voorafgaande vertelling. Die primêre narratief word verleng, maar op 'n ander narratiewe vlak (Patte \& Patte 1978:132).

Dit gebeur nie in die konvergerende narratiewe nie. Die konvergerende narratiewe vertel van die koning se dekreet, Daniël se versoek aan die koning om uitstel en Daniël se tweede gesprek met die koning. Dit onderbreek die formele patroon van die elementêre narratief met ' $n$ vertelling wat ' $n$ bydrae daartoe lewer. In die interseksie van twee narratiewe konvergeer die een in die ander (Culley 1974:169).

Die parallelle narratief bevat gebeure wat gelyktydig met die oorspronklike verhaal plaasvind en wat vertel word, al is dit nie verwant aan die vertelling nie. Die aanstelling van die drie vriende kan so gesien word: hulle het geen bydrae tot die afloop van die vertelling gelewer nie buiten die kursoriese verwysing in vers 17 . Die parallelle narratief word op sy eie geanaliseer. Dit speel hier slegs die rol om as oorgang na die derde verhaal te 
dien, en kan vir doeleindes van verklaring daarby gelees word. Dit is duidelik te wyte aan die hand van 'n redakteur.

Die pertinente transformasies vertoon 'n opvallende patroon. Dit omarm as volg die hele verhaal soos volg: die koning is bekommerd en ontsteld (vv 1b en 3c) versus die koning vereer Daniël omdat hy die bron van ontsteltenis weggeneem het met sy uitleg ( $v$ v 47d en 48a-c).

Hierbinne speel die volgende af:

- die koning se gesprek met die wyse manne, wat 'n divergerende narratief vorm;

- Daniël se gesprek met Arjok wat ook 'n divergerende narratief vorm;

- Daniël se gesprek met sy vriende wat 'n divergerende narratief is;

- Daniël se tweede gesprek met Arjok en Arjok se gesprek met die koning wat 'n konvergerende narratief vorm;

- die uitleg van die droom wat die hoofnarratief vorm (saam met die gegewenheid van die droom in $v 1$ ).

Die oorwegende rol wat dialoog in die verhaal speel, kom duidelik na vore. Om 'n omvang van gesprekke in hoofstuk 2 te gee: van die 135 kernsinne wat geïdentifiseer is, word 112 direk by dialoog betrek.

\subsection{Binêre opposisies}

Eerstens word die koning se gesprek met die towenaars, voorspellers, goëlaars en sterrekykers (NAB-vertaling van v 2) ondersoek. Hier kom drie transformasies voor, wat met die onmoontlikheid van die koning se versoek te doen het:

- die koning vra vir die uitleg van sy droom ( $v$ v 3b-d) versus die wyse manne wat vra dat die koning die droom vertel (4c-d);

- die koning dreig met vernietiging as hulle nie self die droom vertel en die uitleg gee nie, en belowe beloning as hulle kan (5b-6b) versus die wyse manne wat vra dat die koning die droom vertel (7b-c);

- die koning eis dat hulle die droom vertel voor hulle die uitleg gee (8b9b) versus die wyses wat kla dat niemand dit kan doen nie, buiten die gode $(10 b-11 c)$. 


\section{Semiotiese ontleding van Daniël 2}

Die ontwikkeling van die gesprek word duidelik deur die binêre opposisies aangedui: eers vra die koning vir 'n uitleg, en die wyse manne vra dat die koning die inhoud van die droom vir hulle gee. Dan vra die koning dat hulle self die droom vertel asook die uitleg gee, en die wyse manne vra (asof hulle nie hulle ore kan glo nie) dat die koning die droom vertel. Vervolgens eis die koning dat hulle die droom vertel, as bewys dat hulle die uitleg kan gee, en dan (asof die werklikheid uiteindelik tot hulle deurdring) erken hulle dat hulle nie kan nie (Patte \& Patte 1978:36). Dié gesprek is op repetisie gebaseer. Om enkele voorbeelde te noem:

- $\quad$ vertel die droom aan u knegte en ons sal die betekenis openbaar ( $\mathrm{v}$ 4 en 7);

- die woord van my staan vas (vv5 en 8);

- die wet is een, en staan vas (vv 9 en 15).

Uit die koning se dekreet vloei Daniël se gesprek met Arjok, as hy die vier Jode vir teregstelling soek:

- Daniël wil weet hoekom die dekreet so hard is (v 15b) versus Arjok wat dit verduidelik (15c);

- Daniël vra tyd van die koning om die uitleg te gee (16a-b) versus Daniël wat sy vriende vra om vir die openbaring van die geheim te bid (vv 17a-18a);

- die drie vriende bid saam met Daniël (18a) versus Daniël wat die droom en uitleg ontvang (19a).

Hierop volg Daniël se tweede gesprek met Arjok. Dié gesprek vloei uit Daniël se loflied voort nadat God in 'n naggesig aan hom die geheim van die droom openbaar het:

- Daniël prys God omdat Hy die bron van wysheid is (21c-22c) versus Daniël wat vra dat Arjok nie die wyse manne doodmaak nie omdat hy die uitleg ontvang het (24d-e).

In Arjok se gesprek met die koning kom 'n opvallende verwikkeling voor, wat binêr so voorgestel kan word:

- Arjok sê vir die koning dat hy iemand gekry het wat die droom kan uitlê (25b-c) versus die koning wat vir Daniël vra of hy die droom en uitleg kan openbaar (26a-b). 
Daniël se antwoord is doelbewus ' $n$ binêre opposisie:

- die raadgewers, voorspellers, towenaars en sterrekykers kan nie die geheim openbaar nie (27b) versus die God van die hemel wat kan en het (28a-b);

- Daniël wat bely dat hy nie die uitleg gekry het oor hy wys is nie (30a) versus Daniël wat die uitleg gekry het omdat God die uitleg aan die koning wil gee (30b).

In die uitleg van die droom is die eerste deel beskrywend, terwyl die tweede deel, die uitleg, op transformasies wys:

- Nebukadnesar se ryk is die kop van goud wat oor alles heers (37a-38c) versus die ryk wat hierna kom wat nie so belangrik is nie (39a-b);

- die tweede ryk is van silwer versus die derde ryk wat hierop volg en wat oor die hele wêreld heers (39c-d);

- die derde ryk is van brons versus die ryk wat hierna kom wat alles vergruis en fyn stamp (40a-b);

- die vierde ryk is van yster versus die ryk wat hierop volg wat verdeeld is en wat vanweë ondertrouery deels sterk en deels swak is (41a-43b);

- die vyfde ryk is deels van yster en deels van klei versus 'n ewige koninkryk wat hierna deur God opgerig word, en wat die aardse koninkryke vernietig en wat vir ewige bestaan (44a-d).

Die uitleg van die droom, met sy beskrywing van verskillende ryke, kan soos volg opgesom word:

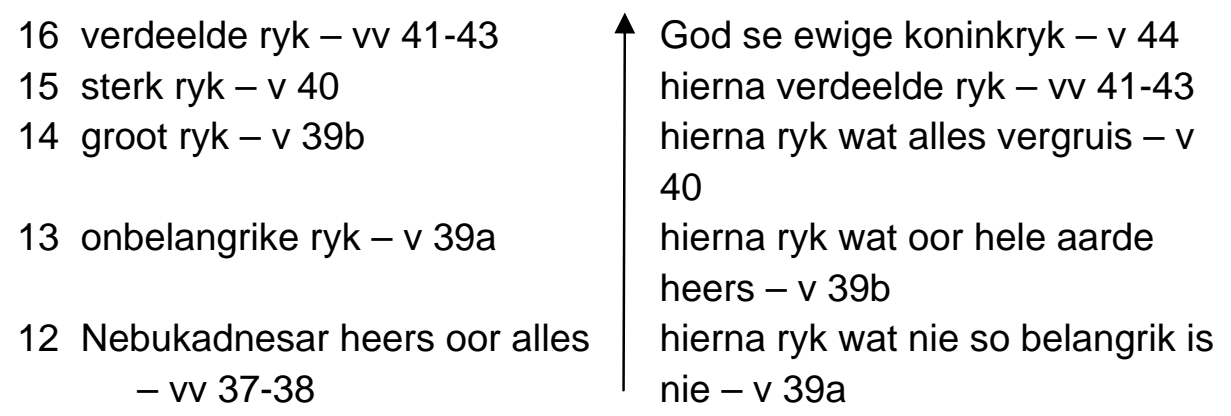


Semiotiese ontleding van Daniël 2

Om die pertinente transformasies op te som:

\begin{tabular}{|l|l|}
\hline $\begin{array}{l}11 \text { ek het nie uitleg oor ek wys is } \\
10 \text { wyse kan nie }\end{array}$ & $\begin{array}{l}\text { ek het uitleg ter wille van u } \\
\text { God van hemel kan }\end{array}$ \\
\hline
\end{tabular}

\begin{tabular}{|c|c|}
\hline $\begin{array}{l}9 \text { Arjok sê vir koning van Daniël } \\
8 \text { Daniël prys God - bron van } \\
\text { wysheid }\end{array}$ & $\begin{array}{l}\text { koning vra vir Daniël } \\
\text { Daniël vra dat wyses nie } \\
\text { vernietig word nie }\end{array}$ \\
\hline
\end{tabular}

\begin{tabular}{ll|l}
\hline & Daniël en vriende bid & Daniël ontvang geheim
\end{tabular}

6 Daniël vra uitstel om uitleg te Daniël vra vriende om te bid vind

5 Daniël vra uit oor dekreet $\quad$ Arjok verduidelik

4 koning vra vir droom en uitleg $\quad$ wyses erken hulle onvermoë

3 koning vra vir droom en uitleg wyses vra vir droom

\begin{tabular}{|l|l|}
\hline 2 koning vra vir uitleg & wyses vra vir droom \\
\hline
\end{tabular}

\begin{tabular}{|l|l|}
\hline 1 koning is ontsteld & koning is nie meer ontsteld \\
\hline
\end{tabular}

Die eerste paar begin en sluit die verhaal af. Dit kan weergegee word met:

$$
\begin{array}{cl}
\text { Probleem - vers } 1 \quad \text { versus } & \begin{array}{l}
\text { Oplossing van probleem - } \\
\text { verse } 48-49 .
\end{array}
\end{array}
$$

Die episode van die gesprek tussen die koning en die wyse manne (2-4 hierbo) staan in die vorm:

$\begin{array}{ll}\text { Versoek - verse } 2-3, \quad \text { versus } & \text { Onvermoë om aan } \\ 5-6,8-9 & \text { versoek te voldoen - } \\ & \text { verse } 4,7,10-11 .\end{array}$


Daniël se gesprek met Arjok en die gevolg daarvan (5-7) kan soos volg opgesom word met:

Probleem vir Daniël - versus Oplossing van probleem verse 13-16 - verse 17-45.

Pare 8-11 hoort saam, in dié vorm:

Onvermoë van wyses $\quad$ versus $\quad$ Alvermoë van God.

Die uitleg van die droom staan in die vorm van:

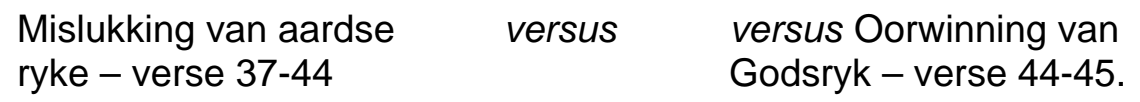

Dit lei tot die volgende binêre opposisies wat die verhaal se pertinente transformasies vorm:

\begin{tabular}{lll} 
& & Oplossing van probleem \\
\hline Mislukking van aardse ryke & versus & Oorwinning van Godsryk \\
\hline Onvermoë van wyses & versus & Alvermoë van God \\
\hline Probleem vir Daniël & versus & Oplossing van probleem \\
\hline Versoek van koning & versus & Onvermoë om aan \\
& & versoek te voldoen \\
Probleem & & \\
& &
\end{tabular}

\section{$2.6 \quad$ Intrige}

Die intrige van die verhaal lê op twee vlakke. In die eerste plek het dit te doen met die koning se onderonsie met die wyse manne. Daniël en sy vriende is deel van dié groep. Die vier Jode deel onskuldig die probleem wat ontstaan uit die onvermoë van die groep wyse manne om die koning se probleem op te los. Die intrige se verloop word doelbewus vertraag deur die drievoudige gesprek tussen die koning en die wyse manne. Die skrywer vertraag verder die ontwikkeling van die intrige, en bou die spanning op deur Daniël se gesprek met Arjok. Let veral op verse 14a en 15a wat herhalend is, en vers $14 \mathrm{~b}$ wat herhalend van verse $12 \mathrm{~b}-13 \mathrm{~b}$ is. Hierna bid Daniël, en ontvang die geheim van die droom en uitleg. Maar die leser hoor nie dadelik wat dit is nie, nes hy nie dadelik sien hoe die koning daarop reageer nie. Eers sing Daniël 'n lang loflied wat 'n herhaling in die koning se reaksie op Daniël se uitleg vind (vgl 21b met 47c, en 22a met 47d; vgl ook 30a met 47e - Burden 1987:201). 


\section{Semiotiese ontleding van Daniël 2}

Die tweede intrige het te doen met die droom en sy uitleg. Dit vorm 'n verhaal binne die groter verhaal. Die uitleg word trapsgewys gegee:

Godsryk - verse 44-45, kola 124-134

Verdeelde ryk - verse 41-43, kola 116-123

Sterk ryk - vers 40, kola 112-115

Groot ryk - vers 39a, kola 110-111

Onbelangrike ryk - vers 39a, kola 108-109

Nebukadnesar se ryk - verse 37-38, kola 103-107

Die een ryk word deur die ander vervang, tot die Godsryk aanbreek wat die verdeelde ryk vernietig en vir ewig bestaan.

Hier kom egter 'n diskrepansie tussen die droom en die uitleg daarvan voor. Die klip (Godsryk) vernietig nie slegs die voete wat deels van yster en deels van klei is nie. Die leser verwag dat die Godsryk slegs die ryk vernietig wat op dié tydstip die wêreldtoneel oorheers. Die konstruksie in vers 35 maak dit duidelik dat die hele beeld vernietig word. Die skrywer skep met dié mededeling die indruk dat God 'n einde aan alle aardse ryke sal maak.

Die rolspelers in die aksie is die koning, wat droom en ontsteld is, die wyse manne wat nie die droom kan openbaar nie, Arjok wat die wyse manne moet teregstel en Daniël aan die koning voorstel, en Daniël wat (saam met sy vriende) bid vir die openbaring van die droom en uitleg, dit ontvang, God loof en die uitleg aan die koning bekend maak. Die intrige draai dus om slegs 'n paar rolspelers, wat veroorsaak dat die verhaal min konsentrasie van die leser vereis. Die eerste intrige se komplikasie lê in die wyse manne se onvermoë om aan die koning se versoek te voldoen. Dit lei tot die tweede intrige met as komplikasie die openbaring van die droom en uitleg.

'n Disgruensie kom in die verhaal voor tussen verse 16 en 25-25. Volgens vers 16a gaan Daniël na die koning om uitstel te vra om die uitleg van die droom bekend te maak, en volgens verse 25a-26b stel Arjok hom aan die koning voor. Dit is duidelik dat die koning nie weet wie Daniël is nie. Die disgruensie wys op 'n naat in die oorlewering van die verhaal wat nie deur die redakteur uitgestryk is nie. Struktuur-analities beskou, funksioneer die disgruensie as die verteller se bydrae om die gang van die vertelling te 
vertraag en die spanning te laat opbou. Die verteller gebruik die herhaling doelbewus as 'n stylelement.

\subsection{Semiotiese vierkante}

Wanneer die transformasies as semiotiese vierkante volgens Greimas se model voorgestel word, kan dit soos volg weergegee word:

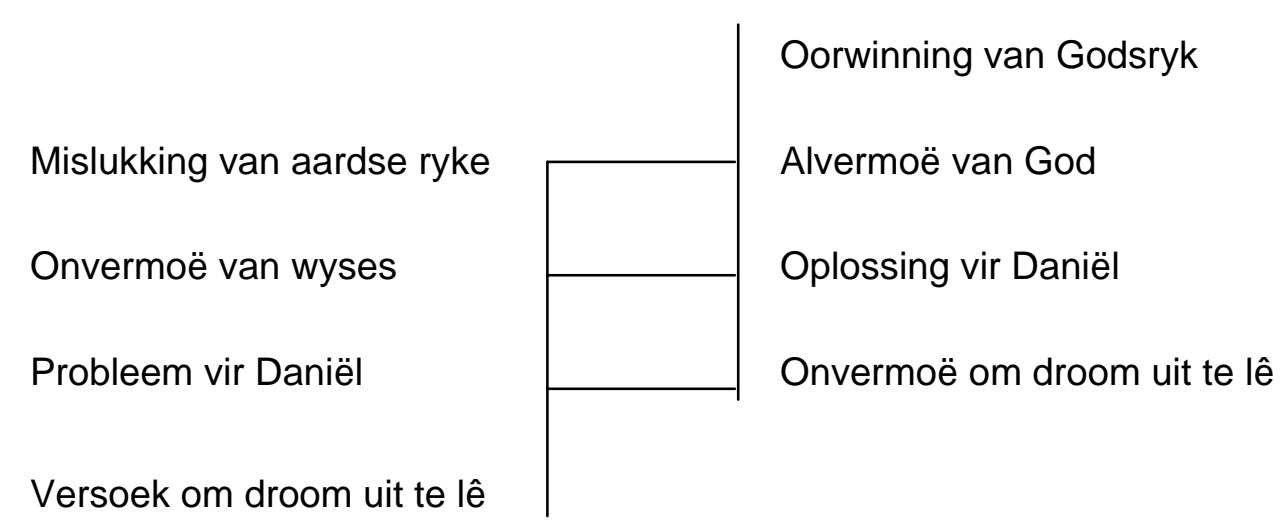

Die groter transformasie wat die hele verhaal kenmerk kan soos volg opgesom word:

Koning se probleem

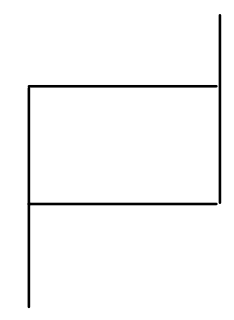

Oplossing - koning se probleem

Dat die hele verhaal in 'n enkele transformasie opgesom kan word, dui daarop dat al die perikoopeenhede in die aksie deel. Die enigste uitsondering is vers 49, wat as inleidend tot die derde verhaal gesien kan word. Dié vers word redaksie-histories as 'n laat toevoeging, as die werk van die verhale se finale samesteller, beskou.

Wanneer die rolspelers as aktante beskryf word, dien die koning (en Arjok, die hoof van die lyfwag en uitvoerder van die koning se opdragte en planne) as opponent. Die koning word opponent as sy dekreet die held se lewe bedreig, al het hy dit nie doelbewus so bedoel of beplan nie. Die hoof van die lyfwag tree namens die koning op.

Die wyse manne (en Daniël en sy vriende, by implikasie) is die subjek in die eerste deel, en Daniël (en sy drie vriende) in die tweede deel. Die objek is die droom en sy uitleg. Die verhaal draai om die droom. 


\subsection{Aktansiële model}

Die aktansiële model kan soos volg voorgestel word:

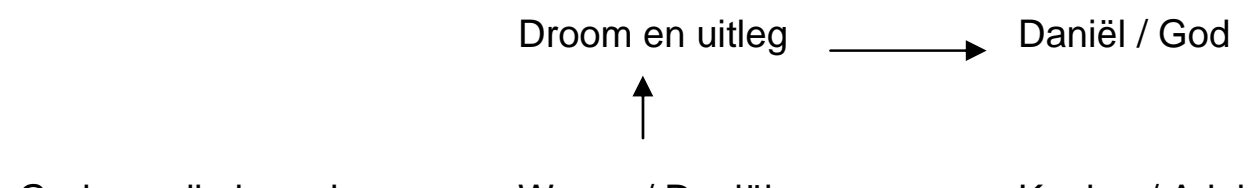

God van die hemel

Wyses / Daniël

Koning / Arjok

Daniël is die ontvanger in die verhaal omdat hy die held is wat beloon word vir sy heldedaad. God deel dié eer met hom, alhoewel slegs in die lofbetuiging van die koning (asook in Daniël se loflied). Die koning gee aan Daniël baie en groot geskenke, en maak hom groot. Hy word aangestel as regeerder oor Babel en hoof van die prefekte van al die wyse manne van Babel ("as hoof van al die koninklike raadgewers" - NAB).

\subsection{Waardes en oortuigings}

Watter waardes of kodes word deur die verhaal belig en aan die leser voorgehou? Die verhaal begin met die mededeling dat die koning 'n droom gehad het. Die droom staan sentraal. Wat wil die droom sê? Koning Nebukadnesar is groot en heers oor die hele aarde (hy is die kop van goud). Na hom kom ander ryke - ryke wat minder belangrik of groter as syne is, of sterk of verdeeld. $\mathrm{Na}$ alles kom die ryk van God. Dié ryk sal die hele aardse bestel van koninkryke vernietig, maar sal self tot in ewigheid bestaan. Die waarde waaroor dit gaan, is God se soewereiniteit. Die vertelling stuur af op die bekendmaking van die Godsryk (Le Roux 1995:16).

Dat die skrywer die waarde van God se soewereiniteit deur sy verhaal onderskryf, word bevestig deur die koning se woorde in reaksie op die uitleg wat Daniël van die droom gee (v 47b). Dit som die waarde mooi op: die God van die hemel is die grootste God, wat oor alle magte op aarde en in die hemel heers. Hy is so groot dat Hy geheime kan openbaar, soos die geheim van die koning se droom en uitleg wat aan Daniël gegee is (Anderson 1984:16).

Dié tema bepaal ook die lied wat Daniël sing (vgl verse 20b-23c). Dit is aan dié God wat wysheid (om geheime te openbaar - 21c, 22a, 22b, 22c, 23b, 23c) en mag (21a, 21b) behoort. En dis Hy wat die wysheid en mag aan Daniël gee (23a). Die wysheid wat Daniël ontvang, lê daarin dat hy die geheim van die koning se droom en uitleg weet. Maar waaruit bestaan die mag? Bestaan dit daarin dat Daniël besef dat die beloning wat op hom wag (omdat hy die geheim van die droom weet) aan hom mag sal besorg? Dat hy as gevolg van sy wysheid (deur die openbaring van God) 'n maghebber sal 
wees? Vers $23 a$ is myns insiens 'n sleutelvers in die verhaal, as direkte herhaling van $20 \mathrm{~b}$. Dié verse lig 'n tweede waarde uit, wat in werklikheid slegs as newe-tema dien. Die tweede waarde dui op die mag wat aan die gelowige Daniël gegee word. God stel hom, nes in Daniël 1, in 'n magsposisie van verantwoordelikheid. Dit vorm ook 'n disgruensie tussen die eerste en tweede verhale. In die eerste verhaal word Daniël en sy vriende tien maal beter as die ander wyse manne bevind. Hier word hulle geïgnoreer. Hulle is onbekend by die koning. Het die verteller hierby verby probeer kom met sy jaaraanduiding in Daniël 2:1? Die verhaal in hoofstuk 2 speel immers af voor die opleiding van hoofstuk 1 voltooi is.

In Daniël 1 is die mag wat aan Daniël verleen word, die gevolg van Daniël se beginselvastheid. In Daniël 2 volg die toekenning van mag aan Daniël (in v 48) op sy gebed (in v 18). In albei verhale is Daniël die insieerder. In die eerste neem hy die besluit om hom nie met die kos en wyn van die koning te verontreinig nie, en sy vriende val by sy dieet in. In die tweede verhaal is dit hy wat oor die dekreet navraag doen en sy vriende saamroep om te bid (Culley 1992:10). Sy vriende baat daarby deurdat hulle ook in posisies aangestel word (vgl Dan 1:19c met Dan 2:49).

\section{SINTESE}

Die semiotiese ontleding toon aan dat die narratief van ringskomposisies gebruik maak met die doel om te beklemtoon dat God die mag het om geheime te openbaar. Die verhaal word deur baie kwalifikasies (teenoor funksies) gekenmerk, wat te doen het met die lengte van die verhaal maar ook met die beskrywing van die beeld. Die transformasies lê op verskillende vlakke: die gesprekke tussen die koning en wyse manne, dekreet van die koning, gesprek tussen Daniël en Arjok, gebed van die vier Joodse vriende, uitleg van droom, loflied, en gesprek tussen Daniël en die koning. Die transformasie in die droom bestaan daaruit dat God die wêreldryke oorweldig. Die intrige het te doen met die koning se onderonsie met die wyse manne, asook in die droom en uitleg. Die koning asook Arjok is die opponent, terwyl die wyse manne, asook Daniël en sy vriende by implikasie, die subjek vorm. Die objek is die droom en uitleg. Die verhaal draai om die droom. Die waardes wat beklemtoon word, is, nes in Daniël 1, die soewereiniteit van God en die verantwoordelikheid van die gelowige mens. 


\section{Semiotiese ontleding van Daniël 2}

\section{Literatuurverwysings}

Anderson, R A 1984. Signs and wonders: A commentary on the book of Daniel. Grand Rapids, MI: Eerdmans. (International Theological Commentary.)

Burden, J J 1987. Die boek Daniël, in Burden, J J \& Prinsloo, W S (reds), Tweegesprek met God, 195-220. Kaapstad: Tafelberg. (Die Literatuur van die Ou Testament. Deel 3.)

Calloud, J 1976. Structural analysis of narrative, tr by D Patte. Philadelphia, PA: Fortress.

Culley, R C 1974. Structural analysis: Is it done with mirrors? Interpretation 28:169184.

Culley, R C 1992. Themes and variations: A study of action in biblical narrative. Atlanta, GA: Scholars. (The Society of Biblical Literature Semeia Studies.)

De Saussure, $F$ 1959. Course in general linguistics, tr by W Baskin, edited by C Bally et al. New York: McGraw-Hill.

Fewell, D N 1991. Circle of sovereignty: Plotting politics in the book of Daniel. Nashville, TN: Abingdon.

Joubert, W H 1979. Power and responsibility in the Book of Daniel. DTh dissertation, University of South Africa.

Le Roux, C 1995. Profeet en politiek: Daniël. Die Woord vir die mense. Halfway House: Orion.

Lévi-Strauss, C 1963. Structural anthropology, tr by C Jacobson. Garden City, MI: Doubleday.

Milne, P J 1988. Vladimir Propp and the study of structure in Hebrew Biblical narrative. Sheffield: Almond Press. (Bible and Literature Series.)

Nel, M 2006. 'n Semiotiese ontleding van Daniël 1. HTS 62(2), 501-519.

Patte, D \& Patte, A 1978. Structural exegesis: From theory to practice: Exegesis of Mark 15 and 16: Hermeneutical implications. Philadelphia, PA: Fortress.

Polzin, R 1974. The framework of the book of Job. Interpretation 28, 183-200.

Van Wyk, W C 1983. The structure of Daniel 2:20-23, in Van Wyk, W C (ed), The exilic period: Aspects of apocalypticism, 183-187. OTWSA 25 \& OTWSA 26. Pretoria: University of Pretoria. (Old Testament Essays.)

Watson, W G E 1984. Classical Hebrew poetry: A guide to its techniques. Sheffield: JSOT Press. (Journal for the Study of the Old Testament Supplement Series 26.) 